\title{
KETERAMPILAN BERPIKIR KRITIS MAHASISWA DALAM MEMECAHKAN MASALAH MATEMATIKA BERDASARKAN KETERAMPILAN ABAD 21
}

\author{
Muzayyanatun Munawwarah'1, Nurul Laili1, Mohammad Tohir ${ }^{2}$ \\ ${ }^{1}$ Program Studi Tadris Matematika Universitas Ibrahimy Situbondo \\ 2Universitas Ibrahimy, Situbondo, Indonesia \\ moza.ocey@gmail.com
}

\begin{abstract}
:
Descriptive analysis methode of research describes about increasing subject in the level of critical thinking skills of students in solving mathematics based on 21st-century skills. The subjects research were 28 students of Mathematics Education Study Program at Ibrahimy University of Situbondo. Data collection is done by providing pre-test and study documentation to students. The test is given to collect data related to students' critical thinking skills. Then learning is done based on 21st-century skills. Furthermore, students are given a post-test solving mathematical problem. Data were collected through observations, test results and interview data tested for their validity by triangulation. The data analysis technique used is qualitative descriptive data analysis. The results of this study indicate that: (1) the results of the achievement of indicators of critical thinking of students based on critical thinking stages formulated by Facione, overall the subject of an increase of $7.53 \%$; (2) there was the same highest increase in the achievement of the indicator thinking Facione stage, namely at the Analyze stage (A) for high, medium, and low category subjects respectively, $77.78 \%, 80 \%$, and $44.44 \%$. However, there are still two stages of critical thinking that still need attention for further research, namely at the List (L) and Self-Correct (S) stages classified as still needing special attention in implementing 21st-century skills in learning activities; (3) the level of critical thinking skills of students based on the critical thinking stages formulated by Facione was in the category of "not critical" for the pre-test results and was in the category of "sufficient critical" for the post-test results.
\end{abstract}

Keywords: critical thinking, skills, problems-solving, Mathematics, 21st-Century Skills.

\section{PENDAHULUAN}

Kualitas sumber daya manusia dalam suatu negara merupakan cerminan atas kemajuan dari suatu negara tersebut. Adapun kualitas sumber daya manusia di Indonesia dapat dilihat dari hasil survei HDI (Human Development Indeks) dalam lima tahun berturut-turut berada di peringkat 110 dari 183 negara dengan indeks 0.689. rangking tersebut masih di bawah negara-negara kecil di benua afrika yang sudah merdeka. Sehingga kualitas sumber daya manusia di Indonesia masih sangatlah rendah. Karena kualitas pendidikan di Indonesia masih sangat memprihatinkan, hal ini dapat dilihat dari hasil pengukuran PISA (Programme for international student assessment) pada tahun 2016 indonesia terdapat pada posisi 62 dari 72 negara yang hingga tahun 2018 semakin menurun. Hal ini diukur dari

Content from this work may be used under the terms of the Creative Commons AttributionShareAlike 4.0 International License that allows others to share the work with an acknowledgment of the work's authorship and initial publication in this journal 
kemampuan IPA, membaca dan Matematika. Pengukuran tersebut menggambarkan rendahnya kualitas pendidikan di Indonesia (Tohir, 2019a).

Terkait dengan bidang matematika yang diujikan pada PISA, Prihandoko (Santiana, Sudana, Garminah, \& Hum, 2014) mengungkapkan bahwa matematika merupakan ilmu dasar yang sudah menjadi alat untuk mempelajari ilmu-ilmu yang lain. Sehingga muncul pemikiran bahwa matematika dikatakan sebagai ratu pengetahuan dan filsafat sebagai rajanya. Hal ini dipertegas oleh Carl Friedrich Gauss (Maswar, 2019) mengatakan bahwa "mathematics is the queen of sciences". Matematika merupakan bekal paling mendasar untuk peserta didik dalam meningkatkan kemampuan berpikir logis, kritis, praktis, sistematis, analitis dan kreatif. Keenam kemampuan berpikir tersebut sebagai komponen utama dan penting terkait dengan keterampilan abad ke-21, yaitu berpikir kritis, berpikir kreatif, komunikatif, dan kolaboratif (Abidin \& Tohir, 2019).

Menurut buku P21 (P21, 2014), berpikir kritis terdiri dari (1) reasoning effectively, (2) thinking systems, (3) making decisions, and (4) problem-solving skills. Keterampilan abad 21 sangatlah penting untuk diperhatikan, dipelajari, dan dipahami oleh para guru dan dosen khususnya mahasiswa sebagai calon guru. Oleh karena itu, keterampilan berpikir kritis seseorang perlu selalu asah dan ditingkatkan secara kontinu untuk semua jenjang pendidikan. Karena siswa yang mampu berpikir kritis akan mampu menyelesaikan masalah secara efektif (Snyder \& Snyder, 2008; Peter, 2012; Chukwuyenum, 2013; Arifani, As'ari, \& Abadyo, 2017). Seseorang yang memiliki kemampuan berpikir kritis akan sangat berpengaruh dalam kehidupannya sehari-hari, yaitu akan selalu membuat keputusan yang tepat dan baik. Hal ini diperkuat oleh pendapat Ennis (As'ari \& Irawan, 2016) menyatakan bahwa berpikir kritis sebagai berpikir yang logis dan reflektif yang difokuskan kepada pengambilan keputusan apa yang harus dipercaya atau apa yang harus dilakukan.

Oleh karen itu, peran mahasiswa sebagai calon guru sangatlah penting dalam mempelajari berbagai model pembelajaran yang inovatif dan kreatif, agar keterampilan berpikir kritis siswa harus selalu tetap diasah setiap saat secara kontinu dan berkesinambungan, agar berpikir kritisnya selalu berkembang dan meningkat pada level yang lebih tinggi atau Higher Order Thinking Skills (HOTS). Seperti yang diungkapkan oleh Yulaelawati (Widodo, 2012; Sirait, Jamiah, \& Suratman, 2017) mengatakan bahwa salah satu peran peran guru dalam pembelajaran matematika adalah membantu peserta didik mengungkapkan bagaimana proses yang berjalan dalam pikirannya ketika memecahkan masalah, misalnyadengan cara meminta peserta didik menceritakan langkah-langkah yang ada dalam pikirannya. Hal ini sejalan dengan pembelajaran abad 21 (Tohir, 2019b), yaitu pembelajaran yang menuntut siswa untuk memiliki kompetensi dalam berpikir kritis, berpikir kreatif, komunikatif, dan kolaboratif. Berpikir kritis berdasarkan keterampialn abad 21 menuntut seseorang untuk terampil dalam berpikir. Keterampilan berpikir kritis seseorang akan tumbuh dan berkembang seiring jalannya waktu ketika individu tersebut menghadapi suatu masalah yang relatif baru atau persoalan sebelumnya yang belum pernah terpecahkan, hal ini bisa terjadi dikarenakan ketika seseorang memperoleh informasi baru dan informasi tersebut tersimpan dalam memorinya sehingga antara informasi yang satu dengan yang lainnya saling berhubungan atau saling menata kembali untuk 
suatu tujuan atau menemukan jawaban yang diinginkan. Jadi, perlu adanya pemikiran yang ktitis terhadap suatu masalah yang dihadapi agar informasi yang diddapat benar-benar valid.

Hasil penelitian oleh Kurniawan (2016) tentang keterampilan berpikir kritis menunjukkan bahwa keterampilan berpikir kritis matematis mahasiswa yang dikenai pembelajaran problem solving lebih baik dari pada keterampilan berpikir kritis matematis mahasiswa yang dikenai pembelajaran tradisional. Hasil penelitian oleh Basri, Hasan; Purwanto; As'ari (2019) menunjukkan bahwa: (1) keterampilan berpikir kritis siswa SMP berada dalam kategori rendah; (2) subketerampilan evaluasi, analisis, dan pengaturan diri menjadi sub-keterampilan berpikir kritis terendah yang dikuasai oleh siswa dibandingkan dengan subketerampilan berpikir kritis lainnya. Sedangkan hasil penelitian oleh Arina, Munawaroh, Rosidi, \& Hidayati (2019) menunjukkan bahwa hasil persentase indikator keterampilan berpikir kritis yaitu interpretasi 75,00\%, analisis sebesar 69,06\%, evaluasi sebesar 78,57\%, inferensi sebesar 65,48\% dan eksplanasi sebesar $62,05 \%$ dengan rata-rata $70,13 \%$ dan termasuk kategori keterampilan berpikir kritis yaitu tinggi.

Beberapa hasil opservasi yang didapat oleh peneliti kepada guru matematika di Kota Malang didapat bahwa salah satu penyebab mereka tidak terampil dalam berpikir kritis adalah minimnya kesempatan melatih keterampilan berpikir kritisnya, kurangnya pendampingan, dan kurangnya manajemen waktu mereka untuk mengasah keterampilan berpikir kritisnya. Berdasarkan uraian diatas, problematika dan dinamika tersebut, maka penulis sangat tertarik untuk melakukan penelitian mengenai tingkat keterampilan berpikir kritis mahasiswa Program Studi Tadris Matematika Universitas Ibrahimy Situbondo dalam memecahkan masalah matematika apabila ditinjau dari tahapan berpikir kritis Facione (2011).

Dengan demikian, maka tujuan dalam penelitian ini adalah untuk mendeskripsikan tingkat keterampilan berpikir kritis mahasiswa yang sesuai dengan keterampilan abad 21 dalam memecahkan masalah matematika berdasarkan tahapan Facione. Adapun kelebihan dari penelitian ini adalah penelitian ini dilakukan pembelajaran pemecahan masalah yang sesuai dengan keterampilan abad 21 terhadap mahasiswa matematika di kalangan pesantren salafiah yang dibatasi dalam penggunaan teknologi informasi dan komunikasi, padahal era revolusi industri 4.0 identik dengan penggunaan teknologi dalam pembelajaran pada semua bidang studi. Adapun Rumusan masalah tentang indikator keterampilan berpikir kritis mahasiswa berdasarkan rumusan berpikir kritis yang disusun oleh Facione. Facione (Peter, 2012) menjelaskan bahwa untuk mengetahui aktivitas mental siswa dalam berpikir kritis ketika memecahkan suatu masalah dapat menggunakan langkah-langkah Identify, Define, Enumerate, Analyze, List, Self-Correct. Sehingga dapat disusun indikator proses berpikir kritis dalam memecahkan masalah berdasarkan keenam langkah berpikir kritis tersebut (IDEALS) seperti yang ditunjukkan pada tabel 1 berikut. 
Tabel 1. Indikator Proses Berpikir Kritis Berdasarkan Tahapan Facione

\begin{tabular}{|c|c|c|}
\hline No. & $\begin{array}{l}\text { Tahapan Proses } \\
\text { Berpikir Kritis }\end{array}$ & Indikator Proses Berpikir Kritis \\
\hline 1. & Identify (I) & $\begin{array}{l}\text { - Mampu menyebutkan ide pokok permasalahan } \\
\text { yang dihadapi. } \\
\text { - Mampu mengkomunikasikan kembali ide pokok } \\
\text { permasalahan dengan kata-kata sendiri secara } \\
\text { lisan, tertulis, gambar, atau diagram. }\end{array}$ \\
\hline 2. & Define (D) & $\begin{array}{l}\text { - Mampu menyebutkan apa saja yang diketahui dan } \\
\text { apa yang ditanyakan pada masalah. } \\
\text { - Mampu menginformasika apa yang tidak } \\
\text { digunakan atau tidak diperlukan dalam } \\
\text { menyelesaikan masalah. }\end{array}$ \\
\hline 3. & Enumerate $(\mathrm{E})$ & $\begin{array}{l}\text { - Mampu menyebutkan pilihan-pilihan strategi } \\
\text { dalam menyelesaikan masalah. } \\
\text { - Mampu menemukan strategi yang tepat dan } \\
\text { masuk akal dalam menyelesaikan masalah. }\end{array}$ \\
\hline 4. & Analyze (A) & $\begin{array}{l}\text { - Mampu menganalisis pilihan strategi untuk } \\
\text { - Memilih prosedur penyelesaian. } \\
\text { prosedur penyelesaian yang dipilih }\end{array}$ \\
\hline 5. & List (L) & $\begin{array}{l}\text { - Mampu menyebutkan alasan yang tepat terhadap } \\
\text { pilihan prosedur penyelesaian yang dipilih. } \\
\text { - Mampu menyebutkan alasan bahwa jawaban } \\
\text { yang didapat merupakan jawaban terbaik. }\end{array}$ \\
\hline 6. & Self-Correct (S) & $\begin{array}{l}\text { - Mampu memeriksa kembali secara menyeluruh } \\
\text { terhadap prosedur penyelesaian, sehingga } \\
\text { didapat jawaban terbaik. } \\
\text { - Mampu menarik kesimpulan yang valid bahwa } \\
\text { jawaban yang didapat adalah jawaban terbaik. }\end{array}$ \\
\hline
\end{tabular}

Sedangkan indikator keterampilan berpikir kritis berdasarkan tahapan pacione pada tabel $1 \mathrm{di}$ atas, maka dapat juga disusun tingkat kreteria keterampilam berpikir kritis dalam memecahkan masalah berdasarkan tahapan berpikir kritir Facione seperti yang ditunjukkan pada tabel 2 berikut. 
Tabel 2 Kreteria Tingkat Keterampilan Berpikir Kritis

\begin{tabular}{cl}
\hline Kategori & \multicolumn{1}{c}{ Indikator Tingkat Keterampilan Berpikir Kritis } \\
\hline $\begin{array}{c}\text { Tingkat 4 } \\
\text { (Sangat Kritis) }\end{array}$ & $\begin{array}{l}\text { Mahasiswa dapat menggunakan keenam tahapan berpikir } \\
\text { kritis Facione dengan sempurna dan sangat jelas dalam } \\
\text { mendeskripsikan proses berpikirnya }\end{array}$ \\
Tingkat 3 & $\begin{array}{l}\text { Mahasiswa dapat menggunakan lima tahapan berdasarkan } \\
\text { rumusan berpikir kritis Facione dan jelas dalam } \\
\text { (Kritis) }\end{array}$ \\
$\begin{array}{c}\text { mendeskripsikan proses berpikirnya } \\
\text { Tingkat 2 }\end{array}$ & $\begin{array}{l}\text { Mahasiswa dapat menggunakan empat tahapan } \\
\text { berdasarkan rumusan berpikir kritis Facione dan cukup } \\
\text { jelas dalam mendeskripsikan proses berpikirnya }\end{array}$ \\
Tingkat 1 & $\begin{array}{l}\text { Mahasiswa dapat menggunakan tiga tahapan berdasarkan } \\
\text { rumusan berpikir kritis Facione dan kurang jelas dalam } \\
\text { mendeskripsikan proses berpikirnya }\end{array}$ \\
(Kurang Kritis) & Mahasiswa hanya dapat menggunakan satu atau dua \\
Tingkat 0 & danapan saja berdasarkan rumusan berpikir kritis Facione \\
(Tidak Kritis) &
\end{tabular}

\section{METODE PENELITIAN}

Jenis penelitian deskriptif dengan pendekatan kualitatif merupakan metode penelitian yang digunakan dalam penelitian ini. Penelitian kualitatif menganut latar belakang alami di mana sebuah penelitian berlangsung (ia memandang konteks secara keseluruhan). Dalam hal ini, manusia berfungsi sebagai instrumen. Metode kualitatif membutuhkan analisis data induktif dan pengembangan teori, yang semuanya didasarkan pada data, yang bersifat deskriptif dan lebih mementingkan proses yang sedang diselidiki. Penelitian ini dibatasi oleh fokusnya, kriteria spesifik untuk memastikan validitas data, dan desain sementara. Juga, data kualitatif dihasilkan melalui keputusan bersama (Tohir \& Wardani, 2017; Tohir, Susanto, Hobri, Suharto, \& Dafik, 2018; Tohir, 2019b; Erviana, 2019). Menurut Saryono (Syarifah, 2017; Hadi \& Faradillah, 2018; Ruswana, 2019) mengatakan bahwa penelitian kualitatif adalah penelitian yang digunakan untuk menyelidiki, menggambarkan, menjelaskan, menemukan kualitas atau keistimewaan dari pengaruh sosial yang tidak dapat dijelaskan, diukur atau digambarkan melalui pendekatan kuantitatif. Namun, penelitian kualitatif ini lebih mementingkan hasil, daripada proses, dan diterapkan dengan menganalisis kinerja mahasiswa pada beberapa tugas yang diberikan, agar mendapatkan rincian mengenai keterampilan berpikir kritis. Setelah itu, efektivitas metode pembelajaran yang dioperasionalkan dapat dibuktikan dengan hasil analisis data. Sedangkan subjek penelitian ini adalah mahasiswa Program Studi Tadris Matematika Universitas Ibrahimy Situbondo 
sebanyak 28 orang. Para mahasiswa diharapkan memberikan ilustrasi yang komprehensif tentang tingkat keterampilan berpikir kritis mereka.

Teknik pengumpulan data adalah langkah paling penting dalam penelitian karena menentukan proses mendapatkan data yang akurat, yang kemudian dianalisis jawaban mahasiswa pada masalah yang diberikan. Data dikumpulkan dengan memberikan test, yaitu pre test dan post test. Test tersebut diberikan untuk mengumpulkan data yang berkaitan dengan keterampilan berpikir kritis mahasiswa. Data yang dikumpulkan direduksi, disajikan, disimpulkan, dan diverifikasi. Validitas data dipastikan dengan triangulasi, pengecekan sejawat, dan observasi diperluas. Sedangkan teknik analisis data dilakukan dengan cara: (1) menganalisis tiap keterampilan berpikir kritis mahasiswa berdasarkan indikator keterampilan berpikir kritis tahapan Facione, (2) mengelompokkan hasil analisis data dalam keterampilan berpikir kritis mahasiswa, (3) menganalisis keterampilan berpikir kritis mahasiswa, dan (4) menganalisis faktor-faktor yang dapat mempengaruhi tingkat keterampilan berpikir kritis mahasiwa.

Data dan sumber dalam penelitian ini diperoleh berdasarkan hasil nilai IPK (Indeks Prestasi Kumulatif) mahasiswa, hasil observasi, hasil pre test dan post test keterampilan berpikir kritis mahasiswa clon guru dalam memecahkan masalah matematika, dan data wawancara. Kemudian, data yang dikumpulkan melalui hasil observasi, hasil tes dan data wawancara tersebut diuji keabsahannya dengan triangulasi. Triangulasi merupakan usaha mengecek kebenaran data atau informasi yang diperoleh oleh peneliti dari berbagai sudut pandang berbeda dengan cara mengurangi sebanyak mungkin bias yang terjadi pada saat pengumpulan data dan analisis data (Tohir, Abidin, Dafik, \& Hobri, 2018). Pendekatan kualitatif digunakan untuk mengetahui tingkat keterampilan berpikir kritis mahasiwa. Adapun Penyajian data dalam penelitian kualitatif dapat dibuat dalam deskripsi singkat dan hubungan antar kategori. Sedangkan bentuk penyajian data yang paling sering digunakan dalam penelitian kualitatif adalah teks naratif. Penyajian data meliputi pengklasifikasian dan identifikasi data, menuliskan kumpulan data yang terorganisir dan terkategori sehingga dapat ditarik kesimpulan. (Tohir, 2019b). Tahap terakhir adalah menarik kesimpulan berdasarkan kelompok data, dalam hal ini tentang tingkat keterampilan berpikir kritis ketika memecahkan masalah matematika.

\section{HASIL DAN PEMBAHASAN}

Hasil nilai IPK mahasiswa merupakan data pertama yang didapat oleh peneliti, kemudian berdasarkan nilai IPK tersebut dikelompokkan menjadi tiga kategori kelompok mahasiwa, yaitu subjek kelompok tinggi, sedang, dan rendah. Data kedua didapat dari hasil opservasi kepada subjek saat pembelajaran berlangsung selama tiga pertemuan. Data ketiga didapat berdasar data hasil pre test dan post test pemecahan masalah matematika, kemudian data tersebut dianalisis dan ditrianggulasikan dengan wawancara serta dipadukan dengan hasil observasi untuk mendapatkan data yang valid dan objektif. Keterampilan berpikir kritis mahasiswa dalam memecahkan masalah matematika berbentuk soal uraian yang dianalisis berdasarkan indikator keterampilan berpikir kritis tahapan Facione. Kemudian, dianalisis juga ketercapaian indikator berpikir kritis 
mahasiswa untuk subjek kelompok tinggi, subjek kelompok sedang, subjek kelompok rendah, subjek penelitian secara keseluruhan. Setelah itu, dianalisis juga tingkat keterampilan berpikir kritis mahasiswa yang telah didapat dari data hasil ketercapaian indikator proses berpikir kritis berdasarkan keenam langkah berpikir kritis yang dirumuskan oleh Facione.

\section{Hasil Tes Ketercapaian Indikator Berpikir Kritis untuk Subjek Kelompok Tinggi \\ Data hasil ketercapain indikator berpikir kritis mahasiswa untuk subjek} kelompok tinggi didapat berdasarkan hasil pre test dan post test. Pada gambar 1 berikut disajikan hasil ketercapain berpikir kritis untuk subjek kelompok tinggi berdasarkan keenam tahapan berpikir kritis yang dirumuskan oleh Facione.

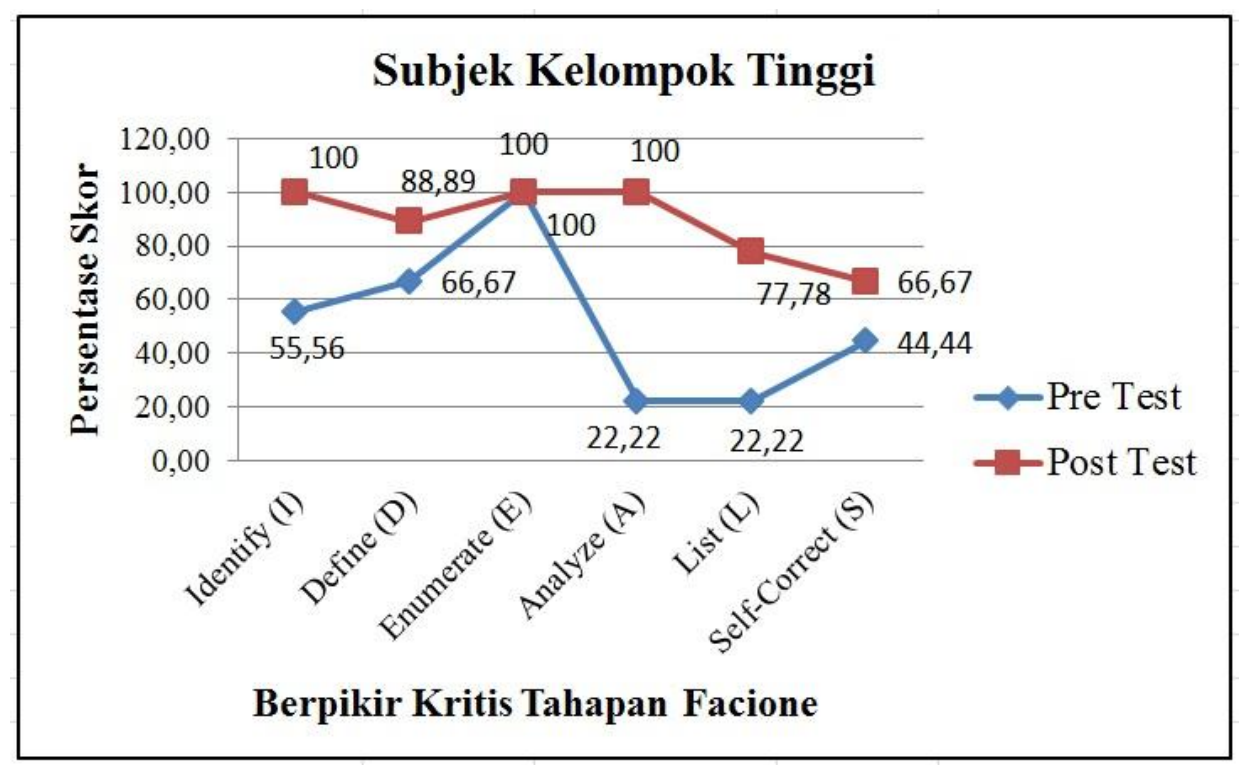

Gambar 1. Persentase Ketercapaian Indikator Berpikir Kritis untuk Subjek Kelompok Tinggi

Berdasarkan hasil persentase skor ketercapaiakn indikator berpikir kritis pada gambar 1 di atas, menunjukkan bahwa hasil rata-rata persentase ketercapaian berpikir kritis untuk subjek kelompok tinggi terjadi peningkatan yang sangat signifikan, yaitu rata-rata persentase pada hasil pre test ada sebear $51,85 \%$, dan pada hasil pos test sebesar $88,89 \%$. Hal ini berarti ada kenaikan ratarata persentase ketercapaian berpikir kritis mahasiswa sebesar 37,04\%. Adapun peningkatan tertinggi untuk mahasiswa kelompok tinggi terdapat pada tahap Analyze (A) dengan peningkatan sebesar 77,78\%. Sedangkan rata-rata hasil persentasi ketercapaian berpikir kritis terendah pada hasil post test yaitu terdapat pada tahap Self-Correct (S), yaitu sebesar 66,67\%. Akan tetapi sebagian besar subjek kelompok tinggi sudah melakukan tahapan tahapan Facione. Berikut ini disajikan hasil jawaban salah satu hasil jawaban subjek kelompok tinggi, kemudian dilakukan wawancara untuk mengecek kebenaran hasil analisi yang didapat oleh peneliti. 
Keterampilan Berpikir Kritis Mahasiswa dalam Memecahkan....

Temuan Jawaban Soal Post Test Mahasiswa untuk Subjek Kelompok Tinggi

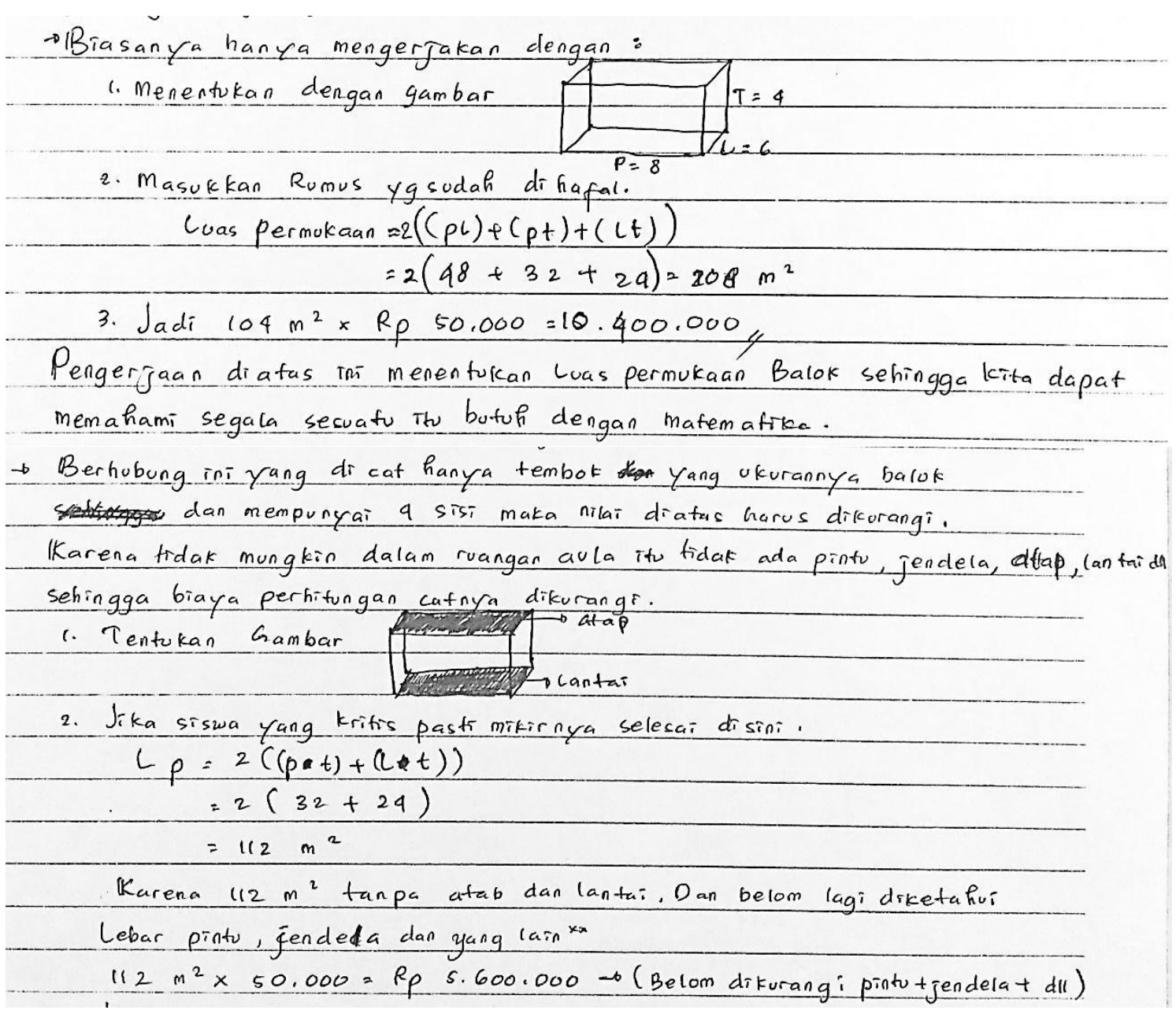

Gambar 2. Hasil Jawaban Subjek A

Berdasarkan hasil jawaban Subjek A pada gambar 2 di atas, menarik perhatian peneliti untuk melakukan wawancara khusus kepada subjek tersebut, bagaimana sebenarnya strategi yang digunakan dalam memecahkan masalah matematika terhadap soal tersebut. Berikut hasil wawancaranya.

Peneliti : Apakah kamu bisa menyebutkan ide pokok permasalahan yang terdapat pada soal?

Subjek A : Ide pokoknya adalah kita dapat mengetahui biaya yang di gunakan untuk mengecat aula dengan ukuran panjang yang sudah di ketahui dan berbentuk balok.

Peneliti : Bisakah kamu mengkomunikasikan kembali ide pokok tersebut dengan kata-kata sendiri secara lisan atau tertulis atau gambar atau diagram?

Subjek A : Bisa di komunikasikn dengan gambar. Akan tetapi tidak bisa di pastikan berapa ukuran dan banyak jendela juga pintu untuk aula tersebut. 
Peneliti : Apakah kamu telah menuliskan yang diketahui dan ditanyakan pada soal?

Subjek A : Sudah. Karena untuk mengerjakan soal tersebut harus memahami apa yang di ketahui dan yang di tanyakan. Agar pengelesaian atau rumusnya tidak keliru.

Peneliti : Apakah kamu bisa menginformasika apa yang tidak digunakan atau tidak diperlukan dalam menjawab soal tersebut?

Subjek A : Wujud soal adalah soal cerita, dari bentuk soal sudah bisa di ketahui panjang, lebar, dan tinggi akan tetapi jika dari kata aula akan membuat suatu pertanyaan lagi. Pada sebuah aula di pastikan memiliki pintu dan juga jendela, aan pada soal tidak di sertakan.

Peneliti : Apakah kamu tau pilihan-pilihan strategi yang mungkin dalam menjawab soal tersebut? Coba sebutkan

Subjek A : Strategi kemungkinan menjawab soal tersebut dengan menggunakan luas permukaan balok tanpa atap dan alas atau menggunakan jumlah luas setiap dinding.

Peneliti : Apakah kamu telah menemukan strategi yang tepat dan masuk akal dalam soal tersebut?

Subjek A : Untuk strategi pengerjaannya dengan menggunakan luas tanpa alas dan atap dapat mempermudah pengerjaannya

Peneliti : Mengapa kamu memilih strategi seperti itu? Coba sebutkan alasannya.

Subjek A : Karena strategi pengerjaan tersebut lebih mudah hanya mengurangi rumus yang sudah ada

Peneliti : Apakah kamu yakin bisa menemukan jawaban yang benar pada soal tersebut? Apa alasannya?

Subjek A : Dengan menggunakan cara tersebut menurut saya ya, jawabannya benar akan tetapi pada soal tidak dicantumkan jendela dan ventilasi udaranya

Peneliti : Apakah kamu mengecek kembali hasil jawabanmu?

Subjek A : Pengecekan kembali saya menggunakan strategi kedua dengan cara penjumlahan luas seluruh Sisi dinding

Peneliti : Apakah kamu sudah menyimpulkan bahwa jawabanmu adalah benar? Bagimana membuktikannya?

Subjek A : Jika keduanya sama maka luas yang ditanyakan benar akan tetapi dari awal kendala pengerjaannya di soal tidak diceritakan ukuran dan banyaknya dari jendela dan juga pintu.

Berdasarkan hasil jawaban Subjek A dan hasil wawancara menunjukkan bawa Subjek A termasuk subjek kategori sangat kritis, karena Subjek A telah mengkritisi soal dan ketercapaian indikator proses berpikir kritis berdasarkan tahapan Facione terpenuhi secara keseluruhan. Pada tahap Identify (I), subjek membaca soal dengan jelas, mampu menyebutkan ide pokok pada soal tersebut, dan mampu mengkomunikasikan kembali ide pokok dengab tertulis atau gambar. 
Pada tahap Define (D) subjek telah mengemukakan yang diketahui dan ditanykan pada soal. Subjek mampu menyebutkan secara menyeluruh informasi apa saja apa yang dapat digunakan dan informasi apa juga yang tidak digunakan dalam menyelesaikan soal tersebut. Pada tahap Enumerate (E) dan Analyze (A), subjek mampu menyebutkan pilihan-pilihan strategi dan menemukan strategi yang tepat dan masuk akal dalam menyelesaikan soal tersebut. Subjek mampu menganalisis pilihan strategi yang digunakan dan subjek menjelaskan bagaimana cara menggunakan prosedur penyelesaian yang dipilih. Pada tahap List (L), subjek mampu memberikan alasan mengapa dalam prosedur penyelesaian menggunakan cara tersebut. Pada tahap Self-Correct (S), subjek mampu memeriksa kembali hasil pekerjaannya secara menyeluruh terhadap prosedur penyelesaian, kemudian diteliti kembali lagi dengan cermat apakah ada yang terlewati ataukah ada kesalahan dalam perhitungan unutk menarik kesimpulan yang valid.

Hasil penelitian ini memperkuat hasil penelitin yang dilakukan oleh Afandi (2017) menujukkan bahwa "subjek kemampuan matematika tinggi. Pada langkah Identify, subjek menentukan pokok permasalahan. Pada langkah Define, subjek mendefinisikan fakta sesuai permasalahan. Pada langkah Enumerate dan Analyze, subjek mendaftar pilihan jawaban yang masuk akal dan menganalisisnya. Pada langkah List, subjek memberikan alasan dalam menyelesaikan soal. Pada langkah Self-Correct, subjek mengecek keseluruhan hasil pekerjaannya". Menurut hasil penelitian Wulantina (Tohir, 2019b) menyimpulkan bahwa siswa dengan kemampuan tinggi pada tahap persiapan siswa mengidentifikasi masalah yang ditanyakan dengan baik, siswa memilih informasi yang dibutuhkan dan informasi yang tidak dibutuhkan dalam penyelesaian masalah dengan tepat. Hal ini juga dipertegas oleh pendapat Hasan (2016) mengatakan bahwa proses berpikir siswa akan berjalan dengan benar sebagaimana yang diharapkan apabila komponen teori pemrosesan informasi yang ada dari stimulus sampai dengan memori jangka panjang pada diri siswa berfungsi dengan baik dan benar pula. Disi lain berdasarkan penelitian Saefudin (Abidin \& Tohir, 2019) menyimpulkan bahwa pada saat menerapkan ide, siswa dengan kemampuan matematika tinggi tidak melakukan kesalahan dalam penyelesaian soal, dan merasa tertantang menyelesaikan soal dengan beragam cara dan jawaban.

Oleh karena itu, siswa yang memiliki kemampuan matematika tinggi maka terlihat pada proses berpikir kritisnya ketika menghadapi masalah, yaitu menggali informasi pada masalah dengan cermat dan teliti sehingga mempertanyakan apabila ada informasi yang kurang pada masalah tersebut, kemudian menysun asumsi sendiri agar masalah tersebut bisa diselesaikan dengan prosedur penyelesaian secara matematik sehingga mendapatkan hasil yang valid setelah diperiksa kembali hasil jawaban yang didapat, apabila diperlukan mencoba menggunakan strategi lain yang lebih efisien dan praktis.

\section{Hasil Tes Ketercapaian Indikator Berpikir Kritis untuk Subjek Kelompok Sedang}

Data hasil ketercapain indikator berpikir kritis mahasiswa untuk subjek kelompok sedang didapat berdasarkan hasil pre test dan post test. Pada gambar 2 berikut disajikan hasil ketercapain berpikir kritis untuk subjek kelompok sedang berdasarkan keenam tahapan berpikir kritis yang dirumuskan oleh Facione. 


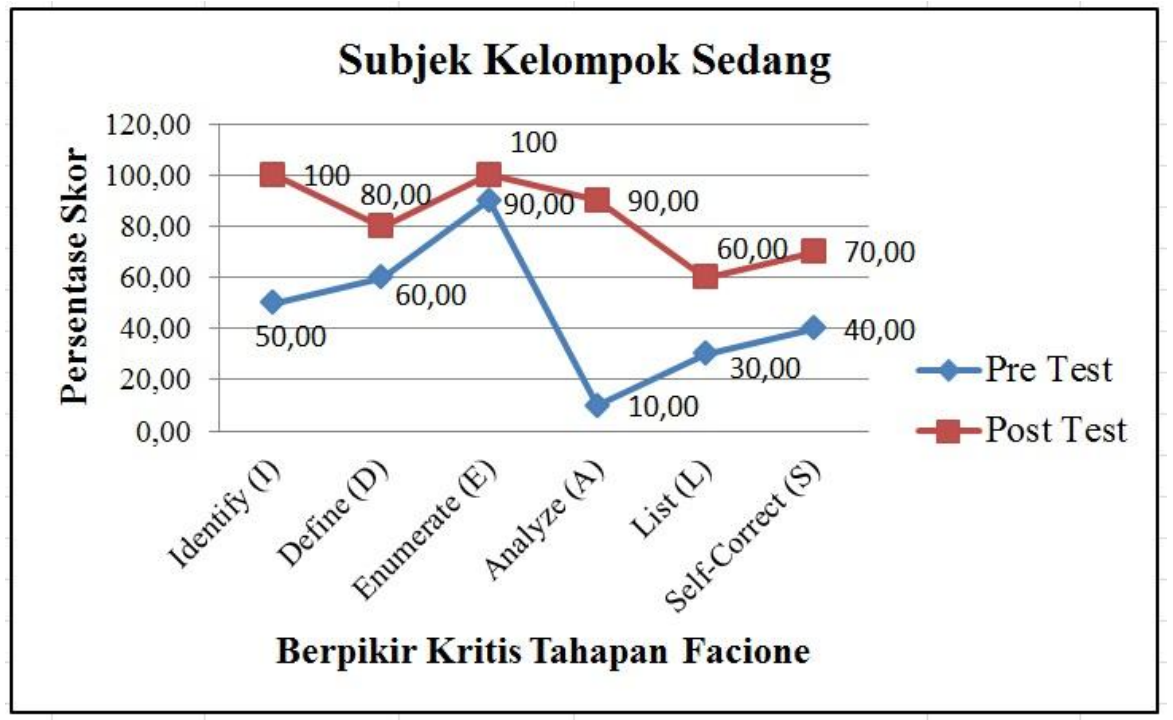

Gambar 3. Persentase Ketercapaian Indikator Berpikir Kritis untuk Subjek Kelompok Sedang

Berdasarkan hasil persentase skor ketercapaiakn indikator berpikir kritis pada gambar 3 di atas, menunjukkan bahwa hasil rata-rata persentase ketercapaian berpikir kritis untuk subjek kelompok sedang terjadi peningkatan yang signifikan, yaitu rata-rata persentase pada hasil pre test ada sebear 46,67\%, dan pada hasil pos test sebesar 83,33\%. Hal ini berarti ada kenaikan rata-rata persentase ketercapaian berpikir kritis siswa sebesar 36,67\%. Adapun peningkatan tertinggi untuk siswa kelompok tinggi terdapat pada tahap Analyze (A) dengan peningkatan sebesar $80 \%$. Sedangkan rata-rata hasil persentasi ketercapaian berpikir kritis terendah pada hasil post test yaitu terdapat pada tahap List (L), yaitu sebesar 60\%. Akan tetapi terjadi kenaikan yang sama antara pre test dengan post test pada tahap List (L) dan Self-Correct (S), yaitu sama-sama sebesar 30\%. Sehingga untuk mengecek kebenaran hasil analisis dilanjutkan dengan wawancara pada subjek kelompok sedang, yakni dapat diuraikan sebagai berikut. 


\section{Temuan Jawaban Soal Pre Test Mahasiswa untuk Subjek Kelompok Sedang}
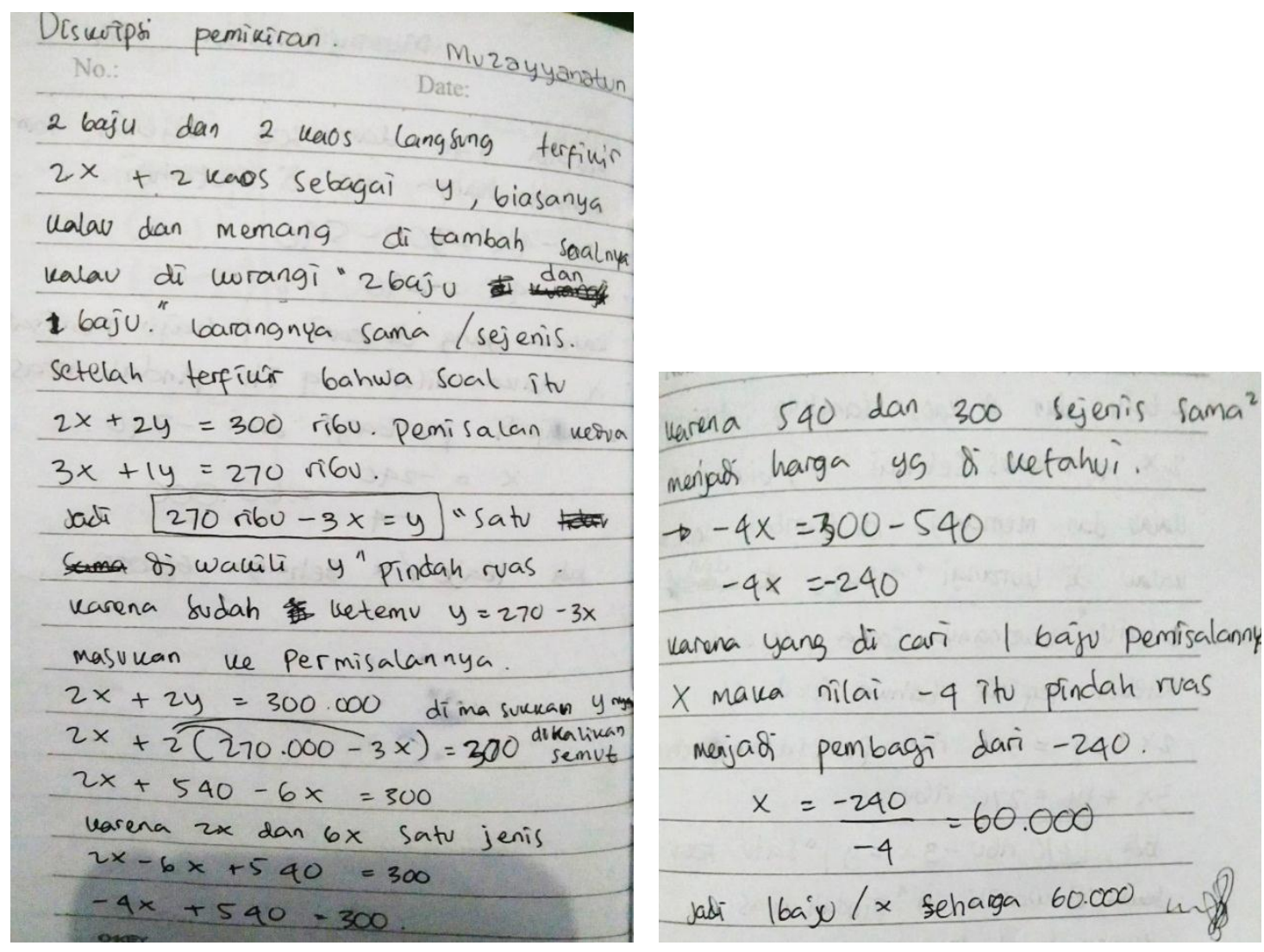

Gambar 4. Hasil Jawaban Subjek B

Peneliti : Apakah kamu bisa menyebutkan ide pokok permasalahan yang terdapat pada soal?

Subjek B : Ide pokok permasalahan adalah mencari harga baju dan kaos pada soal yg di ajukan dengan diketahui beberapa kaos dan baju yg telah di beli sebelumnya.

Peneliti : Bisakah kamu mengkomunikasikan kembali ide pokok tersebut dengan kata-kata sendiri secara lisan atau tertulis atau gambar atau diagram?

Subjek B : Saya dapat mengomunikasikan kembali ide pokok tersebut dengan menggunakan gambar atau diagram untuk mempermudah penyelesaian soal.

Peneliti : Apakah kamu telah menuliskan yang diketahui dan ditanyakan pada soal?

Subjek B : Penulisan yg diketahui dan ditanya dituliskan terlebih dahulu untuk mempermudah pengerjaan dan dapat mengetahui hal penting yg di butuhkan dalam pengerjaan soal tersebut.

Peneliti : Apakah kamu bisa menginformasika apa yang tidak digunakan atau tidak diperlukan dalam menjawab soal tersebut?

Subjek B : Dalam penyajiannya soal tersebut adalah soal cerita yg dibutuhkan dalam soal tersebut adalah yg dituliskan dalam diketahui selain hal 
tersebut adalah hal-hal yg tidak digunakan atau pun tidak di perlukan dalam menjawab soal.

Peneliti : Apakah kamu tau pilihan-pilihan strategi yang mungkin dalam menjawab soal tersebut? Coba sebutkan

Subjek B : Strategi yg saya pakai adalah dengan metode subsitusi, eliminasi, campuran, grafik dan logika.

Peneliti : Apakah kamu telah menemukan strategi yang tepat dan masuk akal dalam soal tersebut?

Subjek B : Strategi yg saya gunakan menggunakan metode campuran karna mempermudah mengetahui harga baju ataupun kaos yg di tanya.

Peneliti : Mengapa kamu memilih strategi seperti itu? Coba sebutkan alasannya.

Subjek B : Karena mengeliminasi terlebih dahulu mencari salah satu variabel yg setelah itu negsubsitusian menurut saya lebih mudah

Peneliti : Apakah kamu yakin bisa menemukan jawaban yang benar pada soal tersebut? Apa alasannya?

Subjek B : Yakin jawaban soal seperti itu dapat di selesaika dengan benar dengan strategi yg saya gunakan

Peneliti : Apakah kamu mengecek kembali hasil jawabanmu?

Subjek B : Pengecekan kembali pada hasil jawaban itu penting untuk mengetahui ketidak telitian karena kesalahan penulisan atau perhitungan

Peneliti : Apakah kamu sudah menyimpulkan bahwa jawabanmu adalah benar? Bagimana membuktikannya?

Subjek B : Sudah ah dengan mensubstitusikan hasil $x$ dan $y$ yang sudah diketahui pada soal awal ataupun ke persamaan 1 dan persamaan 2

Berdasarkan hasil jawaban Subjek B dan hasil wawancara menunjukkan bawa Subjek B termasuk subjek kategori kritis, karena ada satu langkah yang terlupakan unutk ditulis pada lembar jawaban. Hal ini diperjelas dengan hasil wawancara bahwa Subjek B kurang mampu memberikan alasan yang tepat terhadap pilihan prosedur penyelesaian yang dipilih, yakni pada tahap List (L). Hal ini terjadi dikarenakan ada sebesar 33,33\% subjek kelompok sedang masih belum terbiasa memberikan alasan yang tepat terhadap strategi dan prosedur penyelesaian yang dipilih dan cenderung meneru strategi dan prosedur yang pernah tau sebelumnya. Hasil penelitian ini mempertegas dan memperkuat hasil penelitian yang dilakukan oleh Amir (2015) menunjukkan bahwa pada langkah List (A), subjek tidak memberikan alasan tepat atas cara dan jawaban yang digunakan. Menurut Gartmann \& Freiberg (Abidin \& Tohir, 2019) mengatakan bahwa dalam pemecahan masalah terdapat proses menyadari dan mengatur berpikir tentang bagaimana siswa membuat pendekatan terhadap masalah, memilih strategi yang digunakan untuk menemukan pemecahan dan bertanya kepada diri sendiri tentang masalah tersebut. Menurut Tohir (2017) mengatakan bahwa sangat penting bagi siswa untuk menerapkan suatu strategi tertentu pada masalah lain atau mencoba dengan startegi baru yang labih simple atau lebih mudah dipahami, karena dengan demikian proses berpikir siswa dapat selalu 
dikembangkan dan digunakan dengan baik, sehingga keterampilan berpikir tingkat tingginya menungkat ke level yang lebih tinggi juga.

\section{Hasil Tes Ketercapaian Indikator Berpikir Kritis untuk Subjek Kelompok Rendah}

Data hasil ketercapain indikator berpikir kritis mahasiswa untuk subjek kelompok rendah didapat berdasarkan hasil pre test dan post test. Pada gambar 5 berikut disajikan hasil ketercapain berpikir kritis untuk subjek kelompok rendah berdasarkan keenam tahapan berpikir kritis yang dirumuskan oleh Facione.



Gambar 5. Persentase Ketercapaian Indikator Berpikir Kritis untuk Subjek Kelompok Rendah

Berdasarkan hasil persentase skor ketercapaiakn indikator berpikir kritis pada gambar $5 \mathrm{di}$ atas, menunjukkan bahwa hasil rata-rata persentase ketercapaian berpikir kritis untuk subjek kelompok rendah terjadi peningkatan yang cukup bagus, yaitu rata-rata persentase pada hasil pre test ada sebear $18,52 \%$, dan pada hasil pos test sebesar 50\%. Hal ini berarti ada kenaikan ratarata persentase ketercapaian berpikir kritis mahsiswa sebesar 31,48\%. Adapun peningkatan tertinggi untuk mahasiswa kelompok tinggi terdapat pada tahap Analyze (A) dengan peningkatan sebesar 44,44\%. Sedangkan rata-rata hasil persentasi ketercapaian berpikir kritis terendah pada hasil post test yaitu terdapat pada tahap Self-Correct (S), yaitu sebesar 22,22\%.

Meskipun terjadi kenaikan pada tahap Analyze (A), List (L) dan Self-Correct (S), akan tetapi tergolong masih kurang berhasil pembelajaran berdasarkan keterampilan abad 21 untuk sunjek kelompok rendah, sehingga perlu diadakan evaluasi terhadap pembelajaran pemecahan masalah berdasarkan keterampilan abad 21. Memang tidak dipungkiri lagi apabila dilihat berdasarkan hasil analisis secara keseluruhan subjek penelitian ini menunjukkan bahwa proses pembelajaran pemecahan masalah berdasarkan keterampilan abad 21 dapat disimpulkan berhasil, karena presentasi ketercapaian indikator berpikir kritis untuk semua subjek terjadi kenaikan yang sangat signifikan dan persentasi 
ketercapaian indikator berpikir kritis beda di atas 50\% semua tahapan berpikir krtisi yang diruskan oleh Facione, keteyakni dapat dilihat pada gambar 6 berikut ini.

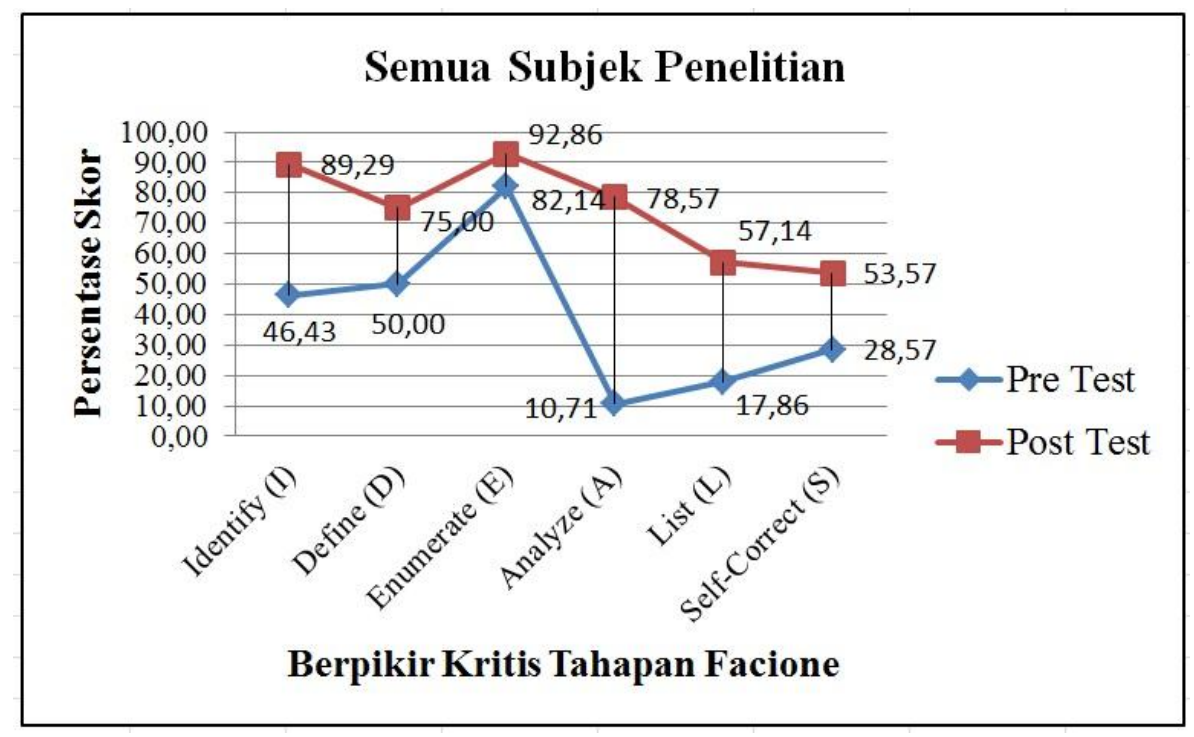

Gambar 6. Persentase Ketercapaian Indikator Berpikir Kritis Mahasiswa

Berdasarkan hasil persentase skor ketercapaiakn indikator berpikir kritis pada gambar 6 di atas, menunjukkan bahwa hasil rata-rata persentase ketercapaian berpikir kritis untuk semua subjek penelitian terjadi peningkatan yang signifikan, yaitu rata-rata persentase pada hasil pre test ada sebear 39,29\%, dan pada hasil pos test sebesar 74,40\%. Hal ini berarti ada kenaikan rata-rata persentase ketercapaian berpikir kritis mahasiswa sebesar 35,12\%. Adapun peningkatan tertinggi untuk mahasiswa kelompok tinggi terdapat pada tahap Analyze (A) dengan peningkatan sebesar 67,86\%. Sedangkan rata-rata hasil persentasi ketercapaian berpikir kritis terendah pada hasil post test yaitu terdapat pada tahap Self-Correct (S), yaitu sebesar 53,57\%. Sehingga hasil ketercapaian secara keseluruhan dapat dinyatakan berhasil kegiatan pembelajaran pemecahan masalah yang berdasarkan keterampilan abad 21. Akan tetapi hasil ketercapain ini jangan berpuas hati dulu, karena subjek pada kelompok rendah masih belum tentu dapat dikatan berhasil atau tidak, hal ini dapat menjadi dasar bahwa keterampilan berpikir kritis siswa dapat dilatih dan diasah secara terus-menerus ketika dalam proses pembelajaran yang perpusat pada siswa (student centered learning).

Menurut L.M. Sartorelli dan R. Swartz (Susilowati, Sajidan, \& Ramli, 2017) menyatakan bahwa terdapat beberapa cara untuk meningkatkan kemampuan berpikir kritis diantaranya adalah: (a) membaca dengan kritis; (b)meningkatkan daya analisis suatu permasalahan dalam suatu diskusi dan mencari solusi terbaik serta menganalisis dampak terburuk dari permasalahan tersebut; (c) mengembangkan kemampuan mengamati atau observasi selanjutnya menyebutkan kelebihan dan kekurangannya, pro-kontra daripemasalahan yang diamati diharapkan akan menggali kemampuan kritis siswa; (d) meningkatkan rasa ingin tahu, kemampuan bertanya dan refleksi, pengajuan pertanyaan bermutu 
yaitu pertanyaan yang tidak secara langsung memiliki jawaban benar atau salah atau tidak hanya satu jawaban benarsehingga menuntut siswa untuk selalu giat berpikir. Oleh karena itu perlu adanya penelitian tindak lanjut terhadap mahasiswa yang berkaitan dengan proses berpikir matematis mahasiswa dalam memecahkan masalah matematika berdasarkan keterampilan abad 21 dengan kegiatan pembelajaran yang lebih inovatif dan menyenangkan.

Menurut Mukhlis \& Tohir (2019) mengatakan bahwa pembelajaran matematika pada Era Revolusi Industri 4.0 ini memiliki visi dan misi untuk membentuk pola berpikir seseorang menjadi mampu berpikir kritis, kreatif, komunikatif, dan kolaboratif. Apabila berbicara mengenai pembelajaran pada Era Revolusi Industri 4.0, maka hal ini berkaitan erat dengan pembelajaran HOTS. Menurut As'ari, Tohir, Valentino, Imron, \& Taufiq (2017) mengatakan bahwa pembelajaran HOTS merupakan pembelajaran berorientasi pada keterampilan berpikir tingkat tinggi, peran guru tidak banyak menerangkan, sebaliknya guru banyak melakukan stimulasi pertanyaan untuk mendorong memunculkanya pikiran-pikiran orsinil siswa.

Dengan demikian, berdasarkan hasil penelitian yang didapat oleh penulis, secara keseluruhan dapat dijabarkan pata tabel 3 berikut tentang tingkat keterampilan berpikir kritis berdasarkan tahapan berpikir krtisi yang dirumuskan oleh Facione.

Tabel 4 Tingkat Keterampilan Berpikir Kritis Mahasiswa

\begin{tabular}{ccc}
\hline \multirow{2}{*}{ Kategori } & \multicolumn{2}{c}{ Persentasi Hasil Tes (\%) } \\
\cline { 2 - 3 } & Pre Test & Pos Test \\
\hline Tingkat 4 & 3,57 & 32,14 \\
(Sangat Kritis) & & 32,14 \\
Tingkat 3 & 10,71 & 10,71 \\
(Kritis) & & \\
Tingkat 2 & 7,14 & 3,57 \\
(Cukup Kritis) & & \\
Tingkat 1 & 17,86 & 3,57 \\
\hline Kurang Kritis) & & \\
Tingkat 0 & 21,43 &
\end{tabular}

Berdasarkan data yang disajikan pada tabel 4, menunjukkan bahwa tingkat keterampilan berpikir kritis mahasiswa berdasarkan tahapan Facione untuk hasil pre tes berada pada kategori "tidak kritis" dengan persentasi terbesar, yaitu 21,43\%; dan tingkat keterampilan berpikir kritis mahasiswa berdasarkan pemecahan masalah untuk hasil post test berada pada dua kategori dengan persentasi terbesar, yaitu "kritis" dan "sangat kritis dengan persentasi 32,14\%. Terjadi peningkatan keterampilan berpikir kritis mahasiswa sebesar 3,57\% untuk kategori "cukup kritis", ada sebesar 21,47\% untuk kategori "kritis", dan ada sebesar 28,57\% untuk kategori "sangat kritis". 
Hasil pre tes menunjukkan bahwa subjek kelompok tinggi dan sedang, ratarata berada pada kategori "kurang kritis" dan subjek kelompok rendah, rata-rata berada pada kategori "tidak kritis". Sedangkan hasil post tes menunjukkan bahwa subjek kelompok tinggi dan sedang, rata-rata berada kategori "kritis" dan subjek kelompok rendah, rata-rata berada pada kategori "kurang kritis". Hal ini menunjukkan bahwa subjek pada kategori yang berbeda memiliki keterampilan berpikir kritisnya berbeda juga berdasarkan karakteristik pribadi masing-masing dan pengetahuan yang didapat sebelumnya. Karena, rata-rata subjek yang berada pada kategori tingggi mampu memberikan penjelasan terhadap yang ditulis/dikerjakan. Hasil penelitian ini memperkuat hasil penelitian sebelumnya yang didapat oleh Guntur, Aliyyatunnisa, \& Kartono (2020) menunjukkan bahwa siswa kategori tinggi mengindikasikan melewati seluruh tahapan, kategori sedang cenderung melewatkan 2 atau 3 tahapan, serta kategori rendah cenderung hanya melewati 2 tahap terakhir.

Perbedaan karakteristik juga tampak dalam kemampuan komunikasi siswa kategori tinggi, sedang, dan tinggi. Hasil penelitian ini juga sesuai dengan hasil penelitian Wulantina (Tohir et al., 2018) yang menyimpulkan bahwa siswa dengan kemampuan tinggi pada tahap persiapan siswa mengidentifikasi masalah yang ditanyakan dengan baik, siswa memilih informasi yang dibutuhkan dan informasi yang tidak dibutuhkan dalam penyelesaian masalah dengan tepat. Hasil penelitian ini juga memperkuat hasil penelitian yang telah dilakukan oleh Guntur, Aliyyatunnisa, \& Kartono (2020) menunjukkan bahwa siswa kategori tinggi mengindikasikan memiliki kemampuan yang lebih dalam mengungkapkan permasalahan dalam kehidupan nyata ke dalam bahasa atau ide matematika dibandingkan dengan kategori yang lain.

Adapun rata-rata subjek yang berada pada kategori sedang mampu memberikan penjelasan terhadap yang ditulis/dikerjakan, akan tetapi belum lengkap. Hal ini sesuai dengan pendapat Wulantina (Tohir, 2019b) mengatakan bahwa siswa dengan kemampuan sedang siswa berusaha menggali informasi, mengidentifikasi masalah yang ditanyakan dengan baik namun kurang konsisten dalam memilih informasi yang dibutuhkan dan informasi yang tidak dibutuhkan dalam penyelesaian masalah. Sedangkan rata-rata subjek yang berada pada kategori rendah tidak mampu memberikan penjelasan terhadap yang ditulis/dikerjakan. Hal ini sesuai dengan pendapat Soekamto (Erviana, 2019) bahwa seseorang dapat melupakan informasi yang telah diperoleh karena ia gagal untuk merubah ingatan jangka pendek menjadi ingatan jangka panjang karena kurang adanya pengulangan atau karena dia tidak dapat mengelompokkan informasi yang diperolehnya.

Dengan demikian, dapat disimpulkan bahwa tidak semua subjek dapat melakukan kelima langkah pemecahan masalah dengan sempurna akan tetapi masih memerlukan waktu untuk berpikir, pada saat seperti itulah maka konflik kognitif akan terjadi pada diri siswa tersebut. Hal ini sesuai dengan pendapat Sabandar (Tohir, 2017) mengemukakan bahwa situasi pemecahan masalah merupakan suatu tahapan di mana ketika individu dihadapkan kepada suatu masalah ia tidak serta merta mampu menemukan solusinya, bahkan dalam proses penyelesaiannya ia masih mengalami kebuntuan. menurut Machmud (Saputri, 2019) mengatakan bahwa pemecahan masalah matematika adalah kesanggupan 
siswa untuk dapat memahami masalah melalui identifikasi unsur-unsur yang diketahui, dinyatakan dan kecukupan unsur yang diperlukan, membuat/menyusun strategi penyelesaian dan merepresentasikannya, memilih/menerapkan strategi pemecahan untuk mendapatkan solusi, dan memeriksa kebenaran solusi dan merefleksikannya. Menurut Tohir (2017) mengatakan bahwa kemampuan memecahkan masalah matematika dipandang sebagai proses tertentu dalam mengkombinasikan aturan-aturan matematis terhadap masalah yang dihadapi.

\section{KESIMPULAN DAN SARAN}

Berdasarkan hasil penelitian, hasil analisis, dan pembahasan pada penelitian ini, maka dapat disimpulkan bahwa: (1) hasil ketercapaian indikator berpikir kritis mahasiswa berdasarkan tapahan berpikir krtis yang dirumuskan oleh Facione, diperoleh adanya peningkatan yang signifikan antara hasil pre test dengan post tes secara keseluruhan dengan adanya perlakukan proses pembelajaran berdasarkan keterampilan abad 21, yaitu untuk tahap Identify (I) terjadi peningkatan persentasi sebesar 42,86\%; untuk tahap Define (D) terjadi peningkatan persentasi sebesar 25\%; untuk tahap Enumerate (E) terjadi peningkatan persentasi sebesar 10,71\%; untuk tahap Analyze (A) terjadi peningkatan persentasi sebesar 67,86\%; untuk tahap List (L) terjadi peningkatan persentasi sebesar 39,29\%; dan untuk tahap Self-Correct (S) terjadi peningkatan persentasi sebesar 25\%; (2) subjek dengan kategori kelompok yang berbeda cenderung memiliki keterampilan berpikir kritis yang berbeda juga berdasarkan karakteristik subjek tesebut dan pengetahuan subjek yang didapat sebelumnya. Hal ini ditunjukkan oleh hasil analisis dalam penelitian ini, yaitu subjek yang berada pada kategori kelompok tinggi rata-rata mampu memberikan penjelasan terhadap yang ditulis/dikerjakan berbedasarkan tahapan berpikir kritis yang disusun oleh Facione. Adapun subjek yang berada pada kategori kelompok sedang rata-rata mampu memberikan penjelasan terhadap yang ditulis/dikerjakan, akan tetapi belum lengkap berbedasarkan tahapan berpikir kritis yang disusun oleh Facione. Sedangkan subjek yang berada pada kategori kelompok rendah rata-rata tidak mampu memberikan penjelasan terhadap yang ditulis/dikerjakan berbedasarkan tahapan berpikir kritis yang disusun oleh Facione; (3) hasil analisis tingkat ketercapain indikator berpikir kritis mahasiswa setelah diperlakukan pembelajaran berdasarkan keterampilan abad 21 diperoleh untuk subjek kelompok tinggi dan sedang rata-rata berada pada kategori "kritis" dan mampu mendeskripsikan proses berpikir matematisnya dalam memcahkan masalah matematika, untuk subjek kelompok rendah rata-rata berada pada kategori "kurang kritis" dan tidak mampu mendeskripsikan dengan jelas proses berpikir matematisnya dalam memecahkan masalah matematika, dan untuk subjek penelitian secara keseluruhan didapat ratarata berada pada kategori "cukup kritis"; (4) berdasarkan hasil wawancara dengan subjek penelitian secara keseluruhan didapat ada beberapa kendala yang dialami oleh subjek pada saat pembelajaran berdasarkan keterampilan abad 21. Hal ini terjadi karena subjek belum terbiasa dengan pembelajaran keterampilan abad 21 yang menekankan berpikir tingkat tinggi (HOTS). Hanya ada beberapa subjek saja yang dapat beradaptasi dengan cepat terhadap pembelajaran berdasarkan keterampilan abad 
21. Pada awalya mereka kaget dengan pembelajaran berdasarkan keterampilan abad 21, akan tetapi lambat-laun menjadi terbiasa.

Bagi mahasiswa hendaknya dapat mengembangkan keterampilan berpikir kritisnya pada setiap saat dan pada saat pembelajaran dikelas. Mahasiswa harus selalu aktif dalam setiap pembelajaran dikelas, akan tetapi tidak hanya berpusat pada matei yang disampaikan dikelas namum mahasiswa harus mandiri dalam mengembangkan pengetahuannya yang dapat mendukung dalam meningkatkan keterampilan berpikir kritisnya melalui studi literatur maupun latihan-latihan mngerjakan soal tipe HOTS, sehingga dapat mengasah keterampilan berpikir kritisnya yang sesuai dengan keterampilan abad 21. Bagi tenaga pendidik atau para peneliti diharapkan agar dapat melakukan penelitian tindak lanjut terhadap penelitian ini, karena dalam penelitian ini masih perlu dicoba pada penelitian eksperimen (experimental research). Hal ini dimaksudkan agar keterampilan berpikir kritis mahasiswa dapat dilatih dan dikembangkan secara kontinu. Selain itu hendaknya pendidik atau para peneliti dapat menerapkan pembelajaran HOTS yang dapat mendukung mahasiswa dalam menungkatkan keterampilan berpikir kreatif dan inovatif. Keterampilan berpikir kreatif dan inovatif mahasiswa dapat dikembangkan, apabila proses pembelajaran dikelas juga mendukung terhadap meningkatnya keterampilan berpikir mahasiswa. Sehingga dalam proses pembelajaran di kelas seorang guru/dosen hendaknya selalu memberikan tugas terstruktur dan tidak terstruktur serta pemecahan masalah yang berorentasi HOTS. 


\section{DAFTAR PUSTAKA}

Abidin, Z., \& Tohir, M. (2019). Keterampilan Berpikir Tingkat Tinggi dalam Memecahkan Deret Aritmatika Dua Dimensi Berdasarkan Taksonomi Bloom. Alifmatika: Jurnal Pendidikan Dan Pembelajaran Matematika, 1(1), 44-60. https://doi.org/10.35316/alifmatika.2019.v1i1.44-60

Afandi, A. (2017). Berpikir Kritis Siswa SMP Dalam Menyelesaikan Soal Cerita Berdasarkan Kemampuan Matematika. Gammath: Jurnal Ilmiah Program Studi Pendidikan Matematika, 1(2), 1-8.

Amir, M. F. (2015). Proses Berpikir Kritis Siswa Sekolah Dasar dalam Memecahkan Masalah Berbentuk Soal Cerita Matematika Berdasarkan Gaya Belajar. JURNAL MATH EDUCATOR NUSANTARA: Wahana Publikasi Karya Tulis Ilmiah Di Bidang Pendidikan Matematika, 1(2), 159-170.

Arifani, N. H., As'ari, A. R., \& Abadyo, A. (2017). Proses Berpikir Siswa Kelas VIII dalam Menyelesaikan Soal Matematika Timss Materi Besar Sudut dalam Bentuk Geometris. Jurnal Pendidikan: Teori, Penelitian, Dan Pengembangan, 2(7), 946-954.

Arina, H. A., Munawaroh, F., Rosidi, I., \& Hidayati, Y. (2019). Peningkatan Keterampilan Berpikir Kritis Siswa Melalui Pendekatan Pembelajaran Berbasis Riset. Natural Science Education Research, 2(1), 17-24.

As'ari, A. R., \& Irawan, E. B. (2016). Variasi Konstruk dalam Pembelajaran Matematika. Malang: Bintang Sejahtera.

As'ari, A. R., Tohir, M., Valentino, E., Imron, Z., \& Taufiq, I. (2017). Buku Guru Matematika (Revisi). Jakarta: Pusat Kurikulum dan Perbukuan, Balitbang, Kemendikbud.

Basri, H., Purwanto, As'ari, A. R., \& Sisworo. (2019). Investigating Critical Thinking Skill of Junior High School in Solving Mathematical Problem. International Journal of Instruction, 12(3), 745-758.

Chukwuyenum, A. N. (2013). Impact of critical thinking on performance in mathematics among senior secondary school students in Lagos State. IOSR Journal of Research \& Method in Education, 3(5), 18-25.

Erviana, T. (2019). Kemampuan Penalaran Matematis Siswa dalam Memecahkan Masalah Aljabar Berdasarkan Gaya Kognitif Field Independent. Alifmatika: Jurnal Pendidikan Dan Pembelajaran Matematika, 1(1), 61-73.

Facione, P. A. (2011). Critical thinking: What it is and why it counts. Insight Assessment, 2007(1), 1-23.

Guntur, M., Aliyyatunnisa, A., \& Kartono, K. (2020). Kemampuan Berpikir Kreatif, Kritis, dan Komunikasi Matematika Siswa dalam Academic-Contructive Controversy (AC). PRISMA, Prosiding Seminar Nasional Matematika, 3, 385392.

Hadi, W., \& Faradillah, A. (2018). Analisis Kemampuan Pemahaman Konsep Mahasiswa Prodi Pendidikan Matematika Terhadap Mata Kuliah Kemuhammadiyahan. Jurnal Pendidikan Islam, 9(1), 85-96. 
Hasan, B. (2016). Proses Berpikir Mahasiswa Dalam Mengkonstruksi Bukti Menggunakan Induksi Matematika Berdasarkanteori Pemerosesan Informasi. APOTEMA: Jurnal Program Studi Pendidikan Matematika, 2(1), 33-40.

Kurniawan, H. (2016). Efektifitas Pembelajaran Problem Solving terhadap Keterampilan Berpikir Kritis Matematis. Prosiding Seminar Nasional Matematika Dan Pendidikan Matematika.

Maswar, M. (2019). Strategi Pembelajaran Matematika Menyenangkan Siswa (MMS) Berbasis Metode Permainan Mathemagic, Teka-teki Dan Cerita Matematis. Alifmatika: Jurnal Pendidikan Dan Pembelajaran Matematika, 1(1), 28-43. https://doi.org/10.35316/alifmatika.2019.v1i1.28-43

Mukhlis, M., \& Tohir, M. (2019). Instrumen Pengukur Creativity and Innovation Skills Siswa pada Era Revolusi Industri 4.0. Indonesian Journal of Mathematics and Natural Science Education, 1(1), 65-73.

P21. (2014). Learning for the 21st Century: A Report and MILE Guide for. Retrieved from http://www.21stcenturyskills.org

Peter, E. E. (2012). Critical thinking: Essence for teaching mathematics and mathematics problem solving skills. African Journal of Mathematics and Computer Science Research, 5(3), 39-43.

Ruswana, A. M. (2019). Analisis Kemampuan Pemahaman Matematis pada Mata Kuliah Aljabar Linier Elementer. Jurnal Cendekia: Jurnal Pendidikan Matematika, 3(2), 293-299.

Santiana, N. L. P. M., Sudana, D. N., Garminah, N. N., \& Hum, M. (2014). Pengaruh Model Pembelajaran Kooperatif Tipe Numbered Heads Together (NHT) Terhadap Hasil Belajar Matematika Siswa Kelas V Sekolah Dasar di Desa Alasangker. MIMBAR PGSD Undiksha, 2(1).

Saputri, R. A. (2019). Analisis Pemecahan Masalah Soal Cerita Materi Perbandingan Ditinjau dari Aspek Merencanakan Polya. WACANA AKADEMIKA: Majalah Ilmiah Kependidikan, 3(1), 21-38.

Sirait, N., Jamiah, Y., \& Suratman, D. (2017). Proses Berpikir Siswa dalam Menyelesaikan Soal Cerita pada Materi SPLTV di SMA. Jurnal Pendidikan Dan Pembelajaran Khatulistiwa, 6(11), 1-8.

Snyder, L. G., \& Snyder, M. J. (2008). Teaching critical thinking and problem solving skills. The Journal of Research in Business Education, 50(2), 90.

Susilowati, S., Sajidan, S., \& Ramli, M. (2017). Analisis keterampilan berpikir kritis siswa madrasah aliyah negeri di kabupaten magetan. Prosiding SNPS (Seminar Nasional Pendidikan Sains), 223-231.

Syarifah, L. L. (2017). Analisis kemampuan pemahaman matematis pada mata kuliah pembelajaran matematika SMA II. JPPM (Jurnal Penelitian Dan Pembelajaran Matematika), 10(2), 57-71.

Tohir, M., Abidin, Z., Dafik, D., \& Hobri, H. (2018). Students Creative Thinking Skills in Solving Two Dimensional Arithmetic Series Through Research-Based Learning. Journal of Physics: Conference Series, 1008(1), 012072. https://doi.org/10.1088/1742-6596/1008/1/012072 
Tohir, Mohammad. (2017). Pengembangan Bahan Ajar Olimpiade Matematika Berdasarkan Model Pemecahan Masalah untuk Meningkatkan Kemampuan Penalaran Matematis Siswa. In Tesis. Magister Pendidikan Matematika Universitas Jember. https://doi.org/10.13140/RG.2.2.31121.79200

Tohir, Mohammad. (2019a). Hasil PISA Indonesia Tahun 2018 Turun Dibanding Tahun 2015. Retrieved December 3, 2019, from Paper of Matematohir website: https://matematohir.wordpress.com/2019/12/03/hasil-pisaindonesia-tahun-2018-turun-dibanding-tahun-2015/

Tohir, Mohammad. (2019b). Keterampilan Berpikir Kreatif Siswa dalam Menyelesaikan Soal Olimpiade Matematika Berdasarkan Level Metakognisi. Alifmatika: Jurnal Pendidikan Dan Pembelajaran Matematika, 1(1), 1-14. https://doi.org/10.35316/alifmatika.2019.v1i1.1-14

Tohir, Mohammad, Susanto, Hobri, Suharto, \& Dafik. (2018). Students' Creative Thinking Skills in Solving Mathematics Olympiad Problems Based on ProblemSolving Polya and Krulik-Rudnick Model. Advanced Science Letters, 24(11), 8361-8364. https://doi.org/10.1166/asl.2018.12563

Tohir, Mohammad, \& Wardani, A. (2017). Analisis Kemampuan Calon Guru Matematika dalam Menerapkan Pendekatan Saintifik Berdasarkan Kurikulum 2013. Prosiding Seminar Nasional Pendidikan Matematika, 2, 431-446. https://doi.org/10.13140/RG.2.2.12666.85444

Widodo, S. A. (2012). Proses Berpikir Mahasiswa dalam Menyelesaikan Masalah Matematika Berdasarkan Dimensi Teacher. Makalah Dipresentasikan Dalam Seminar Nasional Matematika Dan Pendidikan Matematika Dengan Tema "Kontribusi Pendidikan Matematika Dan Matematika Dalam Membangun Karakter Guru Dan Siswa" Pada Tanggal, 10. 